\title{
COMMENTARY
}

\section{The Government's role in industrial relations}

\author{
Hon. Stan Rodger*
}

The Government has practised a policy of non-intervention in the industrial arena since it took office in July last year. It is committed to a consultative approach rather than leaping into the centre of a dispute. In my view the approach is right. The Minister of Labour should not be involved in disputes unless they are likely to adversely affect the national interest. Rather, I believe the Minister should put in place legislation that commands the respect and trust of the participants to ensure that industrial conflict is resolved through effective consultation, mediation, conciliation and arbitration.

Equally, the Government believes unnecessary and unjust penal provisions should be removed. The relevance of penalties in an industrial situation are to be considered in a green paper on industrial relations to be released later this year. So far our Government appears to have had more success with its industrial relations policy than the previous regime. The number of working days lost for the period July 1984 to March this year was 256509 , compared with 274672 working days lost between July 1983 and March 1984. It must be remembered that the latest figures include a wage round, while the first were recorded during the wage freeze under the National Government.

\section{Tripartite talks}

The policy of consultation and an informal approach to industrial relations has been carried over to the tripartite wage talks. The talks were included in legislative changes made last year. The wage conference, as it is now called, is to be held annually over a maximum period of 90 days. It must be convened and chaired by a Minister, or Ministers of the Crown. As is commonly known, the other participants in the conference are representatives of workers in the private and public sectors to be nominated by the Federation of Labour and the Combined State Unions, and representatives of employers from both sectors nominated by the Employers Federation and the State Services Co-ordinating Committee. Beyond that there is no restriction on the number of people that those groups may nominate.

The legislation was deliberately written to ensure an informal approach to participation at the conference. The organisations concerned may nominate whoever they wish to represent them both at the conference proper and in any working parties, such as the one convened to consider the low paid. They may also appoint advisers to assist them. The advantage in this is that it allows the participation of individuals who may have some specific field of expertise which the organisation may feel would be of assistance to the conference. Under this provision, for example, the Employers Federation might nominate a representative from a specific industry, or the FOL might nominate a representative with 
detailed knowledge of social wage provisions.

The primary purpose of the tripartite wage conference is for the parties to consult each other. The parties may, or may not agree to a guideline for the subsequent wage round. It should be stressed that the process of consultation must be seen as a desirable thing in itself, not simply as a means to an end, or as a wage control mechanism.

\section{Union amalgamations}

I am anxious to strengthen the role of central organisations in industrial relations. I believe they should be well funded and well staffed with adequate resources for the provision of legal, economic, industrial health and safety advice. To this end I am anxious to see unions amalgamate. Today, in too many instances, an unacceptably high proportion of union subscriptions are expended upon overhead running costs. Not enough money is left for the needs of a modern workforce. However, most important of all is the need for the union movement to speak with one voice and for that reason $I$ am keen for the New Zealand Council of Trade Unions to proceed. I believe the idea of a single, central union organisation has come of age. When there are 2 trade union centres, for whatever reason, there is divided effort and inevitably the smaller organisation is frozen out of some important discussions and consultation with the Government and other organisations. A well run trade union movement can only benefit the country's industrial relations.

\section{Voluntary unionism}

The Labour Government had a clear mandate from New Zealand voters to repeal the voluntary unionism legislation introduced by the National Government. Labour's programme for democratic government released before last year's elections said: "Labour will provide for trade union membership to be based on the principle of the unqualified preference system." Our Government treated union membership legislation with high priority because of that mandate. It took effect on July 1.

The new legislation does not mean compulsory unionism per se. It gives workers, who have a genuine objection based on conscience or any other deeply held personal conviction to becoming a member or remaining a member of the union, the right to apply for an exemption from the Membership Exemption Tribunal. If the exemption is granted, the tribunal issues a certificate, which unless revoked earlier, is held for life.

I was concerned that under voluntary unionism, trade unions in scattered workplaces suffered. The greatest impact was the practical difficulties experienced by some unions to recruit members as they were hired. The unions most adversely affected were not the most militant, not those with the so-called "left" leadership, but rather the moderate unions. The union membership legislation is based on the principle that those who gain should contribute to the cost of that gain.

\section{Green paper on industrial relations}

My Government is committed to reviewing all existing industrial relations processes, and where necessary improving them. As I mentioned earlier in this article, we are working on a green paper on industrial relations, in consultation with interested groups. The paper will look at a range of matters including the present conciliation, mediation and arbitration structures, and among other issues, it will canvass means of encouraging union amalgamation. I am confident the paper will provide a solid framework for industrial relations in the future. 